\title{
Redes Públicas de Cooperação e o Desenvolvimento Local: a experiência do Programa Nacional de Habitação Rural (PNHR) no Alto Vale do Itajaí
}

\author{
Public Cooperation Networks and Local Development: the \\ experience of the National Rural Housing Program in the Alto \\ Vale do Itajaí
}

\author{
Silmara Sarai da Silva \\ Graduada em Administração de Faculdade Ação. Servidora pública da Prefeitura Municipal de Rio do Sul. Rio do Sul, SC, Brasil. \\ E-mail: silmara.sarai@gmail.com
}

\section{Gabriela Cordioli Coto}

Doutoranda em Administração pela Universidade Federal de Santa Catarina (UFSC). Florianópolis, SC, Brasil. E-mail: gabriela. ccoto@gmail.com

\section{Resumo}

Este artigo, tendo como ponto de partida a Pró Mover, associação criada por agricultores do Alto Vale do Itajaí, que desenvolve ações dentro da rede de desenvolvimento do Programa Nacional de Habitação Rural (PNHR), pretende analisar a real contribuição dessa rede pública de cooperação para o desenvolvimento local no Alto Vale do Itajaí. Por meio da realização de entrevistas semiestruturadas, pesquisa documental e observação participante, coletou-se os dados que foram analisados à luz de categorias relacionadas ao conceito de desenvolvimento local e que foram apresentadas no referencial teórico. Os resultados apontaram para aspectos que tiveram uma contribuição a partir da implementação do PNHR na região, principalmente no que diz respeito à qualidade de vida do público beneficiário. Ainda assim, é necessário potencializar e rever algumas ações para que os objetivos dessa política e da rede em questão sejam atingidos plenamente.

Palavras-chave: Rede Pública de Cooperação. Desenvolvimento Local. Programa Nacional de Habitação Rural.

\section{Abstract}

This article, taking as starting point Pró Mover, an association created by farmers in Alto Vale do Itajaí, that develops actions into the network that developing the National Program of Rural Housing (PNHR), aimed to analyze the real contribution of this public cooperation network for local development in the Alto Vale do Itajaí. By conducting semi-structured interviews, document research and participant observation we collected the data that were analyzed by the light of categories related to local development concept and that were presented in the theoretical framework. The results pointed to aspects that had a contribution from the implementation of PNHR in the region, especially as regards the quality of life of the beneficiary public. Still, it is necessary to strengthen and review some actions so that the objectives of this policy and of the network are met fully.

Keywords: Public Cooperation Network. Local Development. Rural National Housing Policy. 


\section{INTRODUÇÃo}

Em 1988, o Congresso Nacional elaborou uma nova constituição, conhecida também como Constituição Cidadã, que instituiu a participação e a descentralização como pilares de sustentação da gestão pública. Para tanto, os entes municipais do poder público e da sociedade civil ganharam maior visibilidade, autonomia e poder para participar de decisões políticas e da formulação e execução das políticas públicas.

Como forma de alavancar esse processo, novas estruturas sociais foram criadas, possibilitando assim que organizações da sociedade civil, vinculadas aos contextos municipais, se tornassem atores centrais no campo da gestão pública. As redes públicas de cooperação, que se consolidaram no Brasil, principalmente em meados dos anos 2000, são um exemplo disso. Zapata, Amorim e Arns (2007) definem redes de cooperação como conexão e articulação de atores em busca de objetivos comuns.

No caso das redes públicas de cooperação especificamente, representantes de esferas privadas e públicas se vinculam $e$ se organizam em torno de projetos $e$ programas, integrando diferentes setores da sociedade, conhecimentos e tecnologias. A partir do estabelecimento de relações cooperativas mais horizontais, a rede pública de cooperação consegue obter condições favoráveis para a prestação de serviços de interesse público. E mais do que isso, esse tipo de organização possibilita o engajamento de grupos da sociedade civil na gestão pública, de forma a ampliar os processos democráticos ancorados na participação cidadã, sendo essa sua premissa central (MOURA, 1997). Para Cruz, Martins e Quandt (2008), a necessidade de articulação do Estado com entidades da sociedade civil, tornou-se importante, tendo em vista a percepção de que o governo, a sociedade e as organizações, não possuíam condições individuais para o alcance de bons níveis de satisfação da população.

O Estado, a fim de melhorar a prestação de serviços públicos, voltando-se às demandas sociais, tem estimulado esse tipo de articulação para o desenvolvimento das políticas sociais. Sendo assim, as redes têm se configurado como uma estratégia, adotada pelo poder público, para promover a aproximação com os contextos e as problemáticas locais, envolvendo diversos atores sociais em prol do desenvolvimento local.
Atualmente, muitas políticas públicas seguem os moldes de articulação em redes. As políticas habitacionais, que têm ganhado especial atenção do governo brasileiro nos últimos anos, são um exemplo disso. A Política Nacional de Habitação (PNH), com o intuito de garantir moradia digna a todos os segmentos da população, foi construída com base nas políticas delineadas pelo Sistema Nacional de Habitação (SNH), no qual participam representantes de diferentes níveis de governo, assim como atores advindos da sociedade civil.

As políticas habitacionais, por sua vez, além de planejadas, são também executadas por meio de redes de cooperação local, envolvendo instâncias do governo federal, municipal e sociedade civil. Dentro do escopo da Política Nacional de Habitação, está o Programa Nacional de Habitação Rural (PNHR). Criado em 2009, o PNHR objetivou atender aos agricultores e trabalhadores rurais, por meio do subsídio à produção ou reforma de imóveis de famílias agricultoras (BRASIL, 2013b).

Em Santa Catarina, no Alto Vale do Itajaí, a Associação para o Desenvolvimento Social e Aperfeiçoamento do Cidadão - Pró Mover - que dentre as entidades dessa mesma natureza é a com maior representatividade na região, é integrante da rede de cooperação local do PNHR. Desde o ano 2009 a Pró Mover atua preponderantemente em programas de habitação de interesse social e a partir de 2012 passou a trabalhar com o PNHR como Entidade Organizadora, viabilizando os empreendimentos habitacionais.

Dentro desse contexto, neste artigo, tendo como pontos de partida a Associação Pró Mover e as ações desenvolvidas nessa rede, busca-se analisar qual a contribuição da rede pública de cooperação do PNHR, a qual a Pró Mover participa, para o desenvolvimento local no Alto Vale do Itajaí. A Associação, neste estudo, faz a mediação entre os diferentes grupos envolvidos, vinculando a esfera federal, à local. Ressalta-se que o referencial teórico adotado compreende o desenvolvimento para além da esfera econômica, envolvendo elementos de sustentabilidade, valorização do âmbito $e$ cultura local, destacando a importância da participação cidadã para esse fim.

É preciso enaltecer a contribuição dessa pesquisa para a Gestão Social (GS) resgatando as reflexões de Cançado (2011), que delimitou algumas das temáticas e categorias de interesse desse campo, a saber: inte- 
resse pelo bem compreendido $e$ as subcategorias de solidariedade social e sustentabilidade; esfera pública e as subcategorias de comunidades de prática, democracia deliberativa, dialogicidade, interorganizações, intersubjetividade e racionalidade; e por fim o tema da emancipação.

Assumindo a participação cidadã e o desenvolvimento sustentável como categorias centrais de nosso estudo - no sentido de tornar a gestão pública voltada ao bem comum - coaduna-se com a premissa de que a gestão social, em que todos os afetados por políticas públicas são envolvidos nas decisões políticas no âmbito local, é um processo essencial e estruturante do desenvolvimento local. A participação cidadã se desdobra em processos de cidadania deliberativa, compreendida como o envolvimento cidadão nos processos de planejamento e implementação de políticas públicas com vistas ao controle social. Como preconiza Tenório (2012), cada vez mais se fez necessário o envolvimento dos cidadãos nos processos de mudança, tendo em vista a complexificação da vida social (TENÓRIO, 2012).

Entretanto, Nogueira (2004) faz um importante alerta a esse respeito: o aparelho burocrático governamental não é impermeável à incorporação de elementos da vida democrática. A democracia, no discurso neoliberal, se tornou sinônimo de descentralização $e$ não como repartição do poder, mas sim, repartição dos encargos do Estado e também envolver as instâncias subnacionais (principalmente local) na implantação de certas políticas, não apenas para adquirir maior transparência e responsabilidade, mas também, e, principalmente, para obter maior legitimidade e desonerar o aparelho burocrático estatal.

Democratização, descentralização e participação, como ressalta Fedozzi et al. (2012), tornaram-se termos banalizados na atualidade e muitas vezes esvaziados de conteúdo político e potencial de radicalização democrática. Ainda que essa evidência não anule a possibilidade de transformação a partir desses processos, muito menos anule a validade teórica dessas proposições, o momento atual evidencia a necessidade da reflexão crítica.

E é a fim de contribuir para esse debate e para análise de práticas que compõem o arcabouço de interesse da Gestão Social (GS), que se desenvolveu essa pesquisa. A experiência apresentada neste artigo proporcionou reflexões que podem servir para a avaliação do real potencial das atuais políticas sociais desenvolvidas em rede, que, em seu discurso, se apoiam em pressupostos como participação cidadã, horizontalidade das relações, solidariedade social e sustentabilidade, para os processos de Administração Pública Societal ${ }^{1}$, bem como para repensar os próprios moldes da Política Nacional de Habitação.

\section{As Redes Públicas de Cooperação e a Gestão Social}

A mobilização e articulação de atores são estratégias fundamentais para a implementação das políticas públicas, possibilitando aos territórios novas formas de redução das desigualdades sociais (MULS, 2008). Organizações associativas, cooperativas, empresariais, governamentais, assim como agências financiadoras, fundações e bancos de desenvolvimento, desempenham funções estratégicas em um território. Ao se articularem por meio de programas, projetos, parcerias, cooperativas, formando assim uma espécie de "tecido organizacional", constituem outra forma de organização, as redes, que ao somar os diferentes conhecimentos, potencializa a função desses atores de espaço local (FISCHER; MELO, 2004).

Com vistas à promoção de políticas sociais, a formação desses "tecidos" pode ocorrer através da articulação entre os atores da sociedade civil, Estado e mercado, com o sentido de uma estratégia de ação coletiva, propondo uma transformação social em uma determinada localidade (SCHERER-WARREN, 1999).

Como defende Subirats (2012), a valorização de políticas locais, voltadas às problemáticas específicas $e$ ações adequadas para cada realidade, indicam a necessidade de suplantar a visão funcional da gestão, baseada da centralização do poder e preponderância do princípio da eficiência sobre as reais demandas da coletividade e o bem comum ${ }^{2}$, para que se possa consolidar uma agenda com temas mais plurais $e$ amplos. A autossuficiência do poder público deve dar lugar ao estabelecimento de dinâmicas de relação mais

\footnotetext{
${ }^{1}$ A Administração Pública Societal é uma síntese, elaborada por Paes de Paula (2005), da Gestão Social com a gestão pública, em que os processos desta última se pautam pelas premissas de GS.

${ }^{2}$ Apropriou-se aqui do conceito resgatado por Tenório (2012, p. 23), que compreende o bem comum como "subordinação dos interesses individuais ao empreendimento da sociedade".
} 
horizontais, incluindo novos protagonistas políticos, econômicos e comunitários, organizados em rede. O desenvolvimento local está cada vez mais atrelado à capacidade dos governos, das entidades locais e dos cidadãos desenvolverem ações conjuntas com vistas à mudança (SUBIRATS, 2012).

A partir dessa compreensão, as redes, em que se estabelecem relações mais horizontais, indicam uma mudança na estrutura política da sociedade $e$ representam novas formas de organização social, contraponto ao sistema econômico neoliberal dominante (MOREIRA; VIDAL; FARIAS, 2008). As redes públicas de cooperação, de acordo Moura (1998), são resultantes de um conjunto de ideias progressistas, a saber: a constituição de espaços de participação na gestão local para o exercício da cidadania ativa e

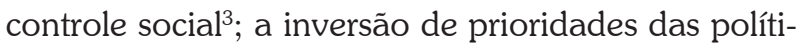
cas locais, de forma a priorizar as demandas sociais; democratização da informação e do acesso aos bens e serviços públicos; construção de uma nova cultura mais democrática. Essas premissas e práticas enfatizam a radicalização democrática e ampliação da cidadania (MOURA, 1998).

O desenvolvimento de políticas públicas, por meio de redes de cooperação, indica o aumento da interdependência entre agentes públicos e privados, baseando-se em valores de cooperação, solidariedade e confiança, valores esses centrais a um processo gerencial dialógico. O potencial de radicalização democrática e a ampliação de uma rede pública de cooperação podem ser identificados a partir de alguns traços, entre eles: a abrangência da rede e a pluralidade dos atores envolvidos, o grau de descentralização (entendida como compartilhamento do poder) das decisões e o tipo de envolvimento de atores da sociedade civil e a natureza dos vínculos estabelecidos (cooperação, corporativismo, conflito, trocas) (MOURA, 1998).

Esses traços e ideais se aproximam das práticas apregoadas pela Gestão Social, no sentido de reconhecer que a participação dos cidadãos, por meio de organizações locais, é essencial para a promoção do desenvolvimento local de forma sustentável. De acordo com Tenório (2005, p. 102), a Gestão Social caracteriza-se como:

\footnotetext{
${ }^{3}$ Apoiou-se em Tenório (2012), compreende-se o controle social como o direito público dos cidadãos, individualmente, ou coletivamente, submeterem o poder político estatal à fiscalização.
}

O processo gerencial dialógico no qual a autoridade decisória é compartilhada entre os participantes da ação (ação que possa ocorrer em qualquer tipo de sistema social - público, privado ou de organizações não-governamentais). O adjetivo social qualificando o substantivo gestão será entendido como o espaço privilegiado de relações sociais em que todos têm o direito à fala, sem nenhum tipo de coação.

É certo que a organização em rede, por meio da reflexão partilhada socialmente, permite que as ações sejam mais pontuais, fazendo com que os atores, engajados em objetivos coletivos, construam estratégias coletivamente, invertendo a lógica top down ${ }^{4}$, como proposto pela Gestão Social. De forma que os atores locais, cooperados na rede, passam a ser atores centrais na solução de problemas sociais coletivos, tendo como horizonte o desenvolvimento local. Cabe salientar que esse processo - desenvolvimento local - envolve esferas para além da econômica (ANDION, 2003).

\section{Por Outro Desenvolvimento Além Do ECONÔMICo}

O sistema capitalista avançou no século XX, no que concerne a evolução da comunicação, do comércio e dos processos de acumulação capitalista, bem como na disseminação de direitos humanos e no aumento da expectativa de vida. Por outro lado, as inconsistências inerentes a esse sistema implicaram na deploração dos recursos naturais não renováveis, na deterioração do meio ambiente e no agravamento de problemas sociais como a pobreza, violação de liberdades políticas e individuais, problematizando assim a atuação dos Estados nacionais na resolução dessas questões, principalmente nos países mais pobres (LEMOS, 2011).

Como assinala Furtado (1980), ainda que o progresso técnico seja condição necessária para a dinâmica da concentração de renda e acumulação, nos países da América Latina, por exemplo, a assimilação de novas técnicas, no impulso desenvolvimentista na década de 1950, não conduziu à elevação do nível de vida médio da população. Outrossim, a natureza dinamicamente dependente do sistema produtivo, a

\footnotetext{
${ }^{4}$ Como lógica top down compreende-se a centralização do poder de decisão político na esfera estatal, delegando à sociedade civil apenas a execução de políticas que são pensadas pelo Estado.
} 
fragilidade monetária e financeira externa e a subordinação político-militar persistiram e, muitas vezes, até se intensificaram em nosso continente a partir do processo de industrialização e crescimento econômico (TAVARES; FIORI, 1997).

A rigor, o conceito de desenvolvimento possui três dimensões distintas: a do incremento da eficácia do sistema social produtivo, a da satisfação das necessidades elementares da população e a da consecução dos objetivos idealizados pelas classes dominantes que competem na utilização de recursos escassos (FURTADO, 1980).

O desenvolvimento de uma sociedade não é, portanto, alheio a sua estrutura social, e, tampouco a formulação de uma política de desenvolvimento e sua implantação podem ser concebidas sem considerar os contextos e necessidades humanas locais. O aumento da eficácia do sistema produtivo, considerado comumente como principal vetor de desenvolvimento, não é condição suficiente para que sejam satisfeitas as necessidades elementares da população. $\mathrm{O}$ aumento produtivo tem encontrado limites na degradação ambiental, tendência a entropia do universo e insatisfação de muitos setores populacionais que ficaram à margem das benesses do avanço tecnológico (FURTADO, 1980).

Nessa direção, Sen (2000) defende que uma concepção adequada de desenvolvimento não pode se restringir questões relacionadas à renda, porquanto deve envolver questões relacionadas à melhoria de vida dos indivíduos. Esse entendimento trouxe para o centro da discussão a dimensão humana, fundamentada em valores como solidariedade, cooperação, valorização das pessoas e respeito ao meio ambiente, propondo o crescimento econômico não como fim, mas como meio de reduzir privações e aflições humanas (SEN, 2000).

Martins (2002, p. 51) preconiza que esse entendimento de desenvolvimento

[...] aparece num contexto em que se esgotam
as concepções de desenvolvimento associadas
a progresso material (acúmulo de riquezas),
pessoal ("ganhar a vida") e ilimitado ("quanto
mais, melhor"), mas, sobretudo, é um produto
da iniciativa compartilhada, da inovação e do
empreendedorismo comunitários.

A partir dessa constatação, o termo desenvolvimento sustentável foi difundido na década de 1980, pela Comissão Mundial sobre o Meio Ambiente e Desenvolvimento da Organização das Nações Unidas (ONU), pelo relatório Brundtland, sendo definido como uma modalidade de desenvolvimento que se preocupa com a satisfação das necessidades atuais das populações, sem comprometer, entretanto, as necessidades das gerações futuras, objetivando ser ecologicamente equilibrado, socialmente justo e economicamente viável (SACHS, 2002).

Destarte, o conceito de desenvolvimento sustentável apontou para a necessidade de redefinição de práticas e estratégias de desenvolvimento das nações, de forma a se pautar pelos princípios da sustentabilidade, da ênfase no local, do desenvolvimento com base em valores locais e do fortalecimento da participação cidadã (ANDION, 2003).

Assim, de acordo com Sachs (2002), a dimensão da sustentabilidade se maximiza adotando os critérios apresentados no quadro a seguir:

\begin{tabular}{|c|c|}
\hline CRITÉrIos & CARACTERIZAÇÃo \\
\hline Social & $\begin{array}{l}\text { Objetiva maior equidade na distribuição de } \\
\text { renda, emprego pleno e qualidade de vida } \\
\text { decente, diminuindo assim a exclusão social } \\
\text { e a desigualdade entre as classes, garantindo } \\
\text { o acesso aos recursos e serviços sociais e } \\
\text { melhorando os direitos e as condições da } \\
\text { população. O autor refere-se à construção do } \\
\text { "ser", ou seja, o capital humano, o "ter", neste } \\
\text { sentido, trata-se de uma distribuição equânime } \\
\text { da renda, permitindo o desenvolvimento dos } \\
\text { seres humanos em condições igualitárias. }\end{array}$ \\
\hline Cultural & $\begin{array}{l}\text { Enfatiza as ideias de mudança nos modos de } \\
\text { pensar e agir da sociedade de maneira a despertar } \\
\text { a autonomia e autoconfiança combinada com } \\
\text { abertura para o mundo e de respeito e valorização } \\
\text { da cultura local, garantindo equilíbrio entre a } \\
\text { tradição e inovação. Fazem parte desta dimensão } \\
\text { a promoção, a preservação e a divulgação } \\
\text { de história, tradições e valores regionais. }\end{array}$ \\
\hline $\begin{array}{l}\text { Ecológico e } \\
\text { ambiental }\end{array}$ & $\begin{array}{l}\text { Se relaciona com a preservação do meio } \\
\text { ambiente, porém não comprometendo a oferta } \\
\text { dos recursos naturais dos quais o homem } \\
\text { necessita para sobreviver, e refere-se também } \\
\text { ao equilîbrio e à manutenção dos ecossistemas. } \\
\text { Ações relacionadas à dimensão ecológica e } \\
\text { ambiental: preservação dos recursos naturais na } \\
\text { produção de recursos renováveis e na limitação } \\
\text { de uso dos recursos não renováveis; limitação } \\
\text { do consumo de combustíveis fósseis; redução } \\
\text { do volume de resíduos e de poluição, por meio } \\
\text { de conservação e reciclagem; autolimitação do } \\
\text { consumo material; utilização de tecnologias limpas } \\
\text { e definição de regras para proteção ambiental. }\end{array}$ \\
\hline
\end{tabular}




\begin{tabular}{|c|c|}
\hline CRITÉRIOS & CARACTERIZAÇÃo \\
\hline Territorial & $\begin{array}{l}\text { Diz respeito ao tratamento equilibrado da } \\
\text { ocupação rural e urbana, além de uma melhor } \\
\text { distribuição territorial das atividades econômicas } \\
\text { e dos assentamentos humanos. Tendo em vista, } \\
\text { o crescimento demográfico acentuado das áreas } \\
\text { urbanas, esta dimensão objetiva melhorias neste } \\
\text { ambiente e elaboração de estratégias ambientais, } \\
\text { conservando as áreas ecologicamente frágeis. }\end{array}$ \\
\hline Econômico & $\begin{array}{l}\text { Objetiva o aumento da eficiência do sistema de } \\
\text { alocação de recursos ou gestão, desenvolvimento } \\
\text { econômico intersetorial e equilibrado e } \\
\text { capacidade de modernização contínua dos } \\
\text { instrumentos de produção. Esta dimensão } \\
\text { preconiza também estabelecer a diminuição das } \\
\text { desigualdades de renda e de padrões de consumo. } \\
\text { A sustentabilidade econômica deve ser medida } \\
\text { através de termos macrossociais e não de critérios } \\
\text { microeconômicos de rentabilidade empresarial. }\end{array}$ \\
\hline Política & $\begin{array}{l}\text { Em se tratando da política nacional, refere- } \\
\text { se a "[...] democracia definida em termo de } \\
\text { apropriação universal dos direitos humanos, } \\
\text { desenvolvimento da capacidade do Estado } \\
\text { em implementar o projeto nacional, em } \\
\text { parceria com todos os empreendedores [...]" } \\
\text { (SACHS, 2002, p. 73), ou seja, a participação } \\
\text { democrática na tomada de decisões, o maior } \\
\text { acesso as informações e compreensão dos } \\
\text { problemas e oportunidades, buscando um } \\
\text { consenso nas decisões coletivas. Ou seja, } \\
\text { uma efetiva descentralização das decisões } \\
\text { políticas na direção do compartilhamento } \\
\text { do poder entre Estado e sociedade civil. }\end{array}$ \\
\hline
\end{tabular}

Quadro 1: Critérios da dimensão sustentabilidade Fonte: Adaptado de Silva (2000), Sachs (2002) e Andion (2003)

Já a dimensão nomeada ênfase no local, reforça a ideia de que o próprio território contém um passado, uma história, uma cultura e abrange as possibilidades futuras de construção de uma nova realidade o qual envolve a participação dos atores de toda comunidade e do uso dos próprios recursos existentes do local (ANDION, 2003). Sachs (2002) enfatiza que as estratégias que promovem o desenvolvimento devem considerar as peculiaridades de cada território.

O desenvolvimento centrado em valores locais, segundo Wolfe (1976 apud ANDION, 2003), indica que caminho a ser escolhido pelos atores é baseado nos seus próprios valores das localidades não em critérios definidos pelo mercado global. Isso quer dizer que esses valores, devem priorizar a preponderância do bem comum sobre os interesses individuais, resgatando valores coletivos locais, assim como a igualdade huma- na, a cooperação e a solidariedade entre os cidadãos, respeitando e valorizando os recursos locais. Para Wolfe (1976 apud ANDION, 2003), a participação dos envolvidos na escolha do caminho para o desenvolvimento, amplia a capacidade da sociedade para funcionar em prol do bem estar dos seus membros.

Sabendo que o desenvolvimento local ocorre de baixo para cima, pois deve partir da própria comunidade, considerando as suas particularidades e atendendo as reais necessidades da população, a participação cidadã se torna primordial para a construção coletiva, incluindo a sociedade civil como protagonista do processo de desenvolvimento.

A participação cidadã, para Fernando Tenório (2012, p. 13), implica no "[...] envolvimento de todos os afetados por políticas públicas ou ações que objetivem o desenvolvimento dos territórios". Assim, além das entidades representativas, a participação cidadã deve envolver a participação direta no planejamento, execução, monitoramento e avaliação das políticas públicas, aliando democracia representativa à democracia participativa. Assim será possível compartilhar efetivamente o poder sobre as políticas públicas de forma a inverter a lógica top down, característica da burocracia. Um processo efetivamente deliberativo deve ter origem em processos de discussão orientados pelos princípios da inclusão, do pluralismo, da igualdade participativa, da autonomia e do bem comum (TENÓRIO, 2012).

As "[...] comunidades locais, desse modo, deixam de ser vistas como objeto das intervenções e assumem o papel de sujeitos ativos do processo de transformação da realidade em que vivem." (ANDION, 2003, p. 1.054).

\section{Metodologia de Pesquisa}

$\mathrm{O}$ interesse pelo tema e pelo objeto de pesquisa teve como ponto de partida a experiência prévia de uma das pesquisadoras, tendo em vista que ela trabalhou na associação Pró Mover durante três anos (de 2010 a 2013), desempenhando a função de Assistente Operacional e acompanhando todo o processo de desenvolvimento das políticas habitacionais pela organização.

Das reflexões realizadas a partir dessa experiência, observações iniciais, conversas informais, levantamen- 
to histórico da organização e da Política Nacional de Habitação (PNH), emergiu o conceito de desenvolvimento sustentável. Dedicou-se ao aprofundamento teórico desse conceito e de outros que emergiram posteriormente, como o conceito de redes de cooperação, para assim desembocar em uma problemática de pesquisa que possibilitasse a contribuição para o contexto de estudo. Para responder à problemática delimitada neste estudo, realizou-se a observação participante combinada à técnica de entrevista e de análise documental.

Agrosino e Perez (2000) assinalam que a observação participante parte do princípio que as vozes são identificadas e interpretadas pelos pesquisadores, não como simples observadores de um fenômeno, mas atuantes nesse (AGROSINO; PEREZ, 2000). A adoção dessa perspectiva, de acordo com Agrosino e Perez (2000), está ancorada nos pressupostos de que os pesquisadores devem desenvolver um papel nas comunidades que estudam, tendo em vista e inviabilidade de alcançar um consenso total entre a visão do pesquisador e pesquisados $e$ na transformação dos pesquisados em colaboradores. Com o intuito de realizar uma interpretação da realidade pesquisada $e$ ao mesmo tempo contribuir para essa, adotou-se o procedimento da observação participante.

Na realização da observação participante, ao longo do ano de 2013, as pesquisadoras se envolveram ativamente em atividades com os associados, auxiliando na orientação, coleta e elaboração de documentos, visitas técnicas nas propriedades, vistorias nas obras e participando das rodadas de conversas e reuniões periódicas juntamente ao grupo de beneficiários. O "caderno de campo" foi um importante instrumento de coleta de dados que os acompanhou nos diferentes momentos e no registro dos trabalhos.

As entrevistas semiestruturadas, realizadas com o auxílio de um roteiro elaborado a partir do referencial teórico, foram de suma importância para identificar os pontos de vista dos diferentes atores envolvidos nesse processo. Para tanto, foram selecionados entrevistados que representativos que possibilitassem a montagem desse "quebra-cabeça". Nesse sentido, foram definidos os critérios para seleção dos entrevistados, tendo por base a visão dos diferentes atores: i) selecionar associados da Pró Mover, contemplando na sua maioria os beneficiários do PNHR; ii) selecionar atores representantes de organizações que compõe a rede pública de cooperação local, considerando o seu envolvimento na execução do PNHR; iii) selecionar atores integrantes da equipe técnica da entidade Pró Mover, com maior tempo de experiência na execução do PNHR.

A partir desses critérios e da observação prévia que se realizou e selecionou - por meio do método não probabilístico de amostragem por julgamento $e$ acessibilidade - 15 entrevistados, que possuem os seguintes vínculos com a Associação e PNHR: um associado fundador da Pró Mover que é atual coordenador geral; um arquiteto responsável técnico pelos projetos de engenharia; uma técnica social responsável pelos projetos de trabalhos sociais; um integrante da equipe técnica da Pró Mover do setor de projetos de trabalhos sociais; dois representantes da Caixa Econômica Federal; um representante do Ministério das Cidades; um colaborador da Secretaria de Agricultura do município de Rio do Oeste em 2012; o vice-prefeito do município de Aurora; um associado beneficiário, que mobilizou mais 40 famílias para a associação e a participação no programa de habitação no município de Lontras; dois associados beneficiários do município de Mirim Doce; dois associados beneficiários do município de Ituporanga; uma associada beneficiária de Rio do Oeste.

Para complementar as informações que surgiram das entrevistas, lançou-se mão da análise documental de históricos, documentos oficiais, pesquisas anteriores, jornais e revistas.

Adotou-se a análise de conteúdo para técnica para análise dos dados, a qual objetiva compreender os produtos da ação e interação humana (MARCONI, 2010). De acordo com Bardin (1977), o método análise de conteúdo contempla etapas como: pré-análise, exploração do material e tratamento dos resultados, que se descreve a seguir:

a) Pré-análise: nessa etapa foram escolhidos os documentos que seriam submetidos à análise $e$ as técnicas que seriam utilizadas para a coleta de dados, a formulação de objetivos e a preparação formal do material.

b) Exploração do material: contemplou a definição de categorias, descrição analítica, codificação e classificação. A partir das categorias centrais elencadas e descritas no referencial teórico, construiu-se um quadro, o qual sintetiza os indicativos referentes a categorias elencadas, que nortearam a análise dos dados deste estudo: 


\begin{tabular}{|c|c|}
\hline InDICATIVOS & CAtegoria \\
\hline $\begin{array}{l}\text { Pluralidade de atores e interesses } \\
\text { envolvidos na rede. }\end{array}$ & Abrangência da rede \\
\hline $\begin{array}{l}\text { Existência de cooperação, } \\
\text { corporativismo, } \\
\text { competição, conflitos. }\end{array}$ & $\begin{array}{l}\text { Natureza dos vínculos } \\
\text { estabelecidos }\end{array}$ \\
\hline Qualidade de vida saudável. & Sustentabilidade social \\
\hline Equidade na distribuição de renda. & $\begin{array}{l}\text { Sustentabilidade social } \\
\text { Sustentabilidade } \\
\text { econômica }\end{array}$ \\
\hline $\begin{array}{l}\text { Valorização do ambiente local: } \\
\text { cultura, recursos, características, } \\
\text { particularidades. }\end{array}$ & $\begin{array}{l}\text { Sustentabilidade cultural } \\
\text { Sustentabilidade territorial } \\
\text { Ênfase no local } \\
\text { Desenvolvimento } \\
\text { centrado em valores }\end{array}$ \\
\hline $\begin{array}{l}\text { Controle e organização do ambiente } \\
\text { local: ocupação rural, equilíbrio e } \\
\text { preservação do meio ambiente. }\end{array}$ & $\begin{array}{l}\text { Sustentabilidade } \\
\text { ecológica e ambiental }\end{array}$ \\
\hline $\begin{array}{l}\text { Eficiência na alocação de recursos ou } \\
\text { gestão, desenvolvimento econômico } \\
\text { intersetorial e equilibrado. }\end{array}$ & $\begin{array}{l}\text { Sustentabilidade } \\
\text { econômica }\end{array}$ \\
\hline $\begin{array}{l}\text { Participação da sociedade } \\
\text { civil na gestão pública } \\
\text { Participação direta no planejamento, } \\
\text { execução, monitoramento e } \\
\text { avaliação das políticas públicas. } \\
\text { Processos de discussão } \\
\text { orientados pelos princípios } \\
\text { da inclusão, do pluralismo, } \\
\text { da igualdade participativa, da } \\
\text { autonomia e do bem comum. }\end{array}$ & $\begin{array}{l}\text { Sustentabilidade política } \\
\text { Participação cidadã } \\
\text { Desenvolvimento } \\
\text { centrado em valores } \\
\text { Grau de descentralização }\end{array}$ \\
\hline
\end{tabular}

Quadro 2: Categorias de análise

Fonte: Elaborado pelas autoras deste artigo

Tratamento dos resultados: nesta etapa, foram interpretados os resultados brutos e analisados de maneira a serem significativos. Com a definição das categorias, foi possível uma análise dos dados obtidos por meio da observação participante e de entrevistas semiestruturadas.

\section{As Políticas Habitacionals no Contexto Brasileiro}

Na Constituição Federal de 1988, a moradia foi considerada um dos direitos sociais, conforme previsto em seu artigo $6^{\circ}$, e através do processo de descentralização, delimitou-se a possibilidade de gestão dos programas sociais, inclusive os de habitação, pelos estados e municípios. O Estatuto da Cidade, aprovado pela Lei Federal n. 10.257/2001, criou novos instrumentos urbanísticos para viabilizar a regularização fundiária, garantindo a função social da propriedade, o planejamento participativo nas políticas urbanas $e$ o acesso universal à cidade.

Em 2003, com o Governo Lula (2003-2010), foi criado o Ministério das Cidades, com o caráter de órgão coordenador, gestor e formulador da Política Nacional de Desenvolvimento Urbano, integrando as políticas relacionadas às cidades - políticas de habitação, saneamento, transporte, mobilidade urbana, trânsito $e$ planejamento territorial. Esse órgão assumiu a responsabilidade de articular e qualificar os diferentes entes federativos para solucionar os problemas habitacionais dos municípios brasileiros (BRASIL, 2013b).

A implementação da Política Nacional da Habitação (PNH), pelo Ministério das Cidades no ano de 2004, garantiu novas condições institucionais para promover a participação da sociedade civil no provimento de acesso à moradia digna a todos os segmentos da população, especialmente os de baixa renda. A PNH delimitou um conjunto de instrumentos para viabilizar a sua efetivação, como o Plano Nacional de Habitação e o Sistema Nacional de Habitação e de Interesse Social (SNHIS), conforme previstos na Lei n. 11.124/2005.

O Plano Nacional de Habitação foi desenvolvido por meio de um processo participativo, organizado por meio de diversos debates regionais. No documento foi expresso um conjunto de ações que possibilitariam construir um caminho no sentido de atingir o objetivo principal do PNH. Entre essas ações estão: a criação de um modelo de financiamento e subsídio para garantir recursos para a urbanização de assentamentos precários e novas unidades de moradia; a implementação do Sistema Nacional de Habitação e de Interesse Social (SNHIS) de forma a consolidar um modelo de política habitacional baseado na descentralização, na articulação intergovernamental e intersetorial, e na participação e controle social; a garantia de acesso à terra urbanizada, legalizada e bem localizada para a provisão de unidades prontas ou lotes; a regularização de assentamentos informais, garantindo a permanência dos moradores de baixa renda; a ampliação e o estímulo a modernização da cadeia produtiva da construção civil voltada à produção de unidades prontas ou lotes e à habitação do mercado popular, buscando obter 
qualidade, menor custo, ganho de escala e agilidade (BRASIL, 2013b).

O SNHIS, por sua vez, estabeleceu as bases da integração entre os três níveis de governo e os agentes públicos e privados, definindo as regras que asseguram a articulação financeira e de recursos necessários à implementação da Política Nacional de Habitação. Esse sistema foi composto por instâncias de gestão e de controle, como o Ministério das Cidades, o Conselho das Cidades, o Conselho Gestor do Fundo Nacional de Habitação de Interesse Social, os Conselhos Estaduais e Municipais, o Fundo Nacional de Habitação de Interesse Social (FNHIS) e os Fundos Estaduais e Municipais de Habitação de Interesse Social (FEHIS e FMHIS) (BRASIL, 2013b).

Dentre os Programas Habitacionais, o Minha Casa Minha Vida, lançado em abril de 2009, com a meta revista em 2012, objetivou construir três milhões de moradias visando atender famílias com renda mensal entre 0 a 10 salários mínimos se tornou o principal. Esse Programa contemplou subsídios e financiamentos para produção ou aquisição de novas unidades habitacionais. Atuando de maneira diferenciada para cada padrão de renda familiar, o Programa Minha Casa Minha Vida foi segmentado em subprogramas, como o Programa Nacional de Habitação Urbana que oferece financiamento às famílias que residem na área urbana com renda mensal de até $\mathrm{R} \$ 5.000,00$; e o Programa Nacional de Habitação Urbana, que atende as famílias com renda bruta mensal de até $\mathrm{R} \$ 1.600,00$, já que elas devem estar organizadas por meio de uma Entidade Organizadora. Voltando-se aos agricultores e trabalhadores rurais, o Programa Nacional de Habitação Rural objetivou subsidiar a produção ou reforma de imóveis às famílias agricultoras (BRASIL, 2013b).

Os beneficiários devem ser organizados sob a forma coletiva por uma Entidade Organizadora (EO), que podem ser cooperativas, associações, sindicatos ou o poder público. Podem ser contemplados com este programa os agricultores familiares, trabalhadores rurais, assentados do Programa Nacional de Reforma Agrária (PNRA), quilombolas, extrativistas, pescadores artesanais, ribeirinhos, indígenas e demais comunidades tradicionais com renda bruta anual até $\mathrm{R} \$$ 60.000,00 (BRASIL, 2013b).

\section{A Pró Mover e o PNHR no Alto Vale do Itajaí}

Os moldes, a partir dos quais se organizaram o Programa Nacional de Habitação Rural em 2009, possibilitaram que seu desenvolvimento se desse por meio da articulação entre organizações governamentais e organizações sem fins lucrativos oriundas da sociedade civil, como é o caso da rede a qual a Associação para o Desenvolvimento Social e Aperfeiçoamento do Cidadão - Pró Mover - participa, e que desenvolve ações do Programa no Alto Vale do Itajaí.

A Pró Mover, fundada no ano de 2000 por agricultores ligados aos movimentos sociais de defesa da agricultura familiar, na cidade de Alfredo Wagner, no Alto Vale do Itajaí, é considerada uma associação civil, sem fins lucrativos, que atua para a conquista dos interesses dos seus associados. Desde, a Associação trabalha com projetos habitacionais que beneficiam famílias de agricultores na região.

Para a execução do PNHR, a Associação desempenha ações em parceria com uma rede pública de cooperação, que envolve atores sociais como o Ministério da Fazenda, Ministério das Cidades, Caixa Econômica Federal e organizações pertencentes à comunidade local, como fornecedores de materiais de construção e mão de obra. Seguindo os apontamentos de Subirats (2012), essa rede é formada por atores tanto do governo, quanto da sociedade civil, que compartilham interesses comuns voltados para o desenvolvimento de serviços de qualidade aos cidadãos da região em questão, no caso, a produção de unidades habitacionais para as famílias agricultoras $e$ melhoria de suas condições de vida com o engajamento da sociedade civil.

Entre as entidades que compõem a rede, pode-se destacar os atores centrais, conforme quadro a seguir:

\begin{tabular}{|ll|}
\multicolumn{1}{|c|}{ AtoRES } & \multicolumn{1}{c|}{ Funções QUE Desempenham Na Rede } \\
\hline Ministério da & $\begin{array}{l}\text { É o responsável pelo repasse dos recursos } \\
\text { financeiros do OGU para aplicação no }\end{array}$ \\
Fazenda (MF) & $\begin{array}{l}\text { Programa (BRASIL, 2013b). Esse ator } \\
\text { se relaciona com os atores Ministério das } \\
\text { Cidades e Caixa Econômica Federal. }\end{array}$ \\
\hline
\end{tabular}




\begin{tabular}{|c|c|}
\hline Atores & Funções QUE DesEmpenham Na ReDE \\
\hline $\begin{array}{l}\text { Ministério } \\
\text { das Cidades } \\
\text { (MCidades) }\end{array}$ & $\begin{array}{l}\text { É o gestor da aplicação dos recursos, } \\
\text { responsável por estabelecer os parâmetros } \\
\text { operacionais do Programa, bem como } \\
\text { acompanhar e avaliar os resultados } \\
\text { obtidos na aplicação dos recursos do OGU } \\
\text { (BRASIL, 2013b). Além de relacionar-se } \\
\text { com o Ministério da Fazenda, o Ministério } \\
\text { das Cidades relaciona-se com a Caixa } \\
\text { Econômica Federal e a Pró Mover. }\end{array}$ \\
\hline $\begin{array}{l}\text { Caixa } \\
\text { Econômica } \\
\text { Federal (CEF) }\end{array}$ & $\begin{array}{l}\text { É o agente operador e financeiro, por } \\
\text { intermédio da Gerência de Desenvolvimento } \\
\text { Urbano e Rural (GIDUR). É responsável } \\
\text { por controlar e acompanhar a execução } \\
\text { orçamentária, pelo repasse de informações } \\
\text { ao Ministério das Cidades, além de analisar } \\
\text { e acompanhar as propostas de intervenção } \\
\text { habitacional, sob os aspectos jurídico, cadastral, } \\
\text { econômico-financeiro e técnicos de arquitetura, } \\
\text { engenharia e trabalho social (BRASIL, } \\
\text { 2013b). A parceria firmada entre a Pró Mover } \\
\text { e a CEF é formalizada através do Termo de } \\
\text { Cooperação e Parceria. A CEF relaciona-se } \\
\text { também com os associados beneficiários. }\end{array}$ \\
\hline Pró Mover & $\begin{array}{l}\text { É a Entidade Organizadora (EO) que viabiliza } \\
\text { a execução do empreendimento. Atua } \\
\text { como representante dos seus associados } \\
\text { beneficiários do Programa. Dentre as suas } \\
\text { atribuições estão: elaborar e apresentar à } \\
\text { Caixa o projeto de intervenção habitacional; } \\
\text { organizar o grupo de beneficiários do } \\
\text { empreendimento; produzir as unidades } \\
\text { habitacionais e promover ações necessárias } \\
\text { relativas à prestação de assistência técnica } \\
\text { para a obra e trabalho técnico social. A Pró } \\
\text { Mover relaciona-se também com o Ministério } \\
\text { das Cidades e os atores locais que auxiliam na } \\
\text { execução do Programa, como as Prefeituras } \\
\text { e Sindicatos locais, além dos Fornecedores } \\
\text { de materiais de construção e mão de obra. }\end{array}$ \\
\hline $\begin{array}{l}\text { Entidades } \\
\text { pertencentes } \\
\text { à comunidade } \\
\text { local } \\
\text { (Prefeituras, } \\
\text { Sindicatos e } \\
\text { Associações } \\
\text { municipais) }\end{array}$ & $\begin{array}{l}\text { São os agentes locais, parceiros da } \\
\text { Pró Mover na execução do Programa. } \\
\text { Têm a função de mobilizar e organizar } \\
\text { os beneficiários do seu município. }\end{array}$ \\
\hline $\begin{array}{l}\text { Fornecedores } \\
\text { de mão } \\
\text { de obra e } \\
\text { materiais de } \\
\text { construção }\end{array}$ & $\begin{array}{l}\text { Correspondem as lojas de materiais de } \\
\text { construção e profissionais de mão de } \\
\text { obra. Possuem a função de produzir } \\
\text { as unidades habitacionais juntamente } \\
\text { com os Associados beneficiários. }\end{array}$ \\
\hline $\begin{array}{l}\text { Associados } \\
\text { beneficiários }\end{array}$ & $\begin{array}{l}\text { Compreendem as famílias associadas à Pró } \\
\text { Mover e beneficiárias do PNHR. Estes são } \\
\text { responsáveis por participar e acompanhar } \\
\text { a execução das obras, reuniões e atividades } \\
\text { realizadas durante todo o processo. }\end{array}$ \\
\hline
\end{tabular}

Quadro 3: Atores da rede e suas funções

Fonte: Elaborado pelas autoras deste artigo
Dessa forma, apresenta-se a rede pública de cooperação local do PNHR, por meio da figura a seguir, elenca os atores e as suas relações:

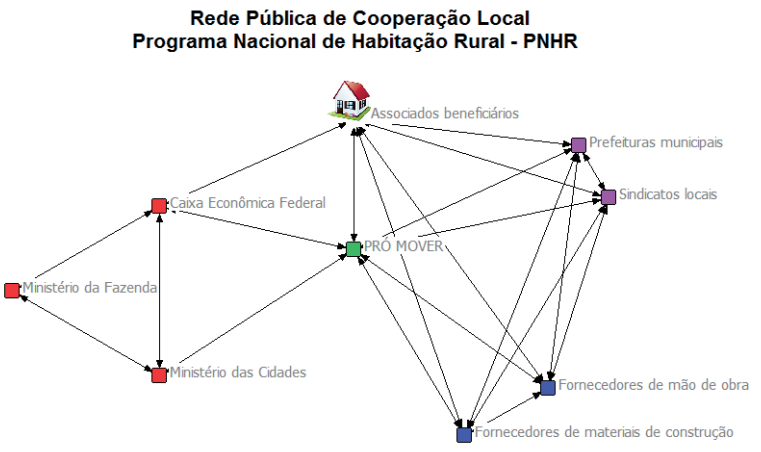

Figura 1: Rede Pública de Cooperação Local - PNHR

Fonte: Elaborada pelas autoras deste artigo

O processo de descentralização, como se propõe nessa rede de cooperação, alvo de estudo, é essencial para ligar o global, no caso Governo Federal, ao local, nesta pesquisa, o Alto Vale do Itajaí. Para isso, entretanto, os agentes locais devem partilhar com entidades federais o poder de decidir e de implementar as ações do Programa.

Ao resgatar os traços, delimitados por Moura (1998), que apontam para o potencial de radicalização democrática de uma rede, foram tecidas algumas considerações importantes. Com relação à abrangência, ao analisar o perfil dos envolvidos na rede identificou-se uma pluralidade de atores, com posicionamentos e pontos de vista distintos. O Estado está representado pelas entidades Ministério da Fazenda, Ministério das Cidades e Caixa Econômica Federal, que são agentes normativos e indutores do Programa. A sociedade civil está representada por uma organização do terceiro setor, a Pró Mover que atua como corresponsável para a realização dos serviços públicos e faz a mediação entre os diferentes grupos de interesse neste processo, bem como pelos fornecedores de mão de obra e material de construção, que atuam para a prestação de serviços $e$ as entidades da comunidade local representam os beneficiários e cidadãos participantes do PNHR.

No que concerne o grau de descentralização, ainda que essa rede tenha o objetivo de, para além de prover condições melhores de vida para a população, consolidar a participação de grupos historicamente à margem da gestão pública - agricultores de baixa renda - no intuito de democratizar as políticas públicas, 
o que se percebe é que, embora o Sistema Nacional de Habitação e Interesse Social seja um espaço aberto aos grupos da sociedade civil, as decisões políticas centrais ainda ficam a cargo preponderantemente do governo federal, delegando aos entes subnacionais, muitas vezes, apenas a implementação das políticas.

Ademais, dentro dos limites do poder decisório que é delegado à rede - forma e critérios de utilização dos recursos - percebe-se que o envolvimento dos beneficiados ainda é bastante incipiente, tendo em vista a limitação do poder decisório que é delegado a eles, como se demonstrará adiante nas análises subsequentes. Ressalta-se também que os parâmetros gerais para implementação da política - valor orçamentário, grupos beneficiados, moldes de construção, e etapas para realização do programa - são preestabelecidos pelo Programa, a cargo do Ministério das Cidades. Com um sistema ainda embrionário, o que se percebe ainda neste campo é que, muito embora o sistema possibilite uma abertura em termos de discussão das políticas, as decisões finais e centrais ainda se concentram no poder público.

Quanto à natureza dos vínculos estabelecidos, pode-se identificar traços de cooperação entre os diferentes integrantes da rede, de maneira a realmente levar a cabo o objetivo do PNHR e negociar os interesses conflitantes.

\section{O PNHR e o Desenvolvimento Local no Alto Vale do Itajaí}

Conforme dados disponibilizados pela Associação Pró Mover (2013), por meio da implementação do PNHR no Alto Vale do Itajaí por meio da Associação, foram contemplados, na sua maioria, agricultores familiares que não possuem casa própria, pertencentes à faixa de renda do Grupo I (renda anual até $\mathrm{R} \$$ $15.000,00)$. No ano de 2012 e 2013, foram contemplados 28 grupos de beneficiários. Ao total são 724 unidades habitacionais rurais em vários municípios do Alto Vale do Itajaí.

Em se tratando da implementação do PNHR, em cada município o qual a Pró Mover estará atuando, são realizadas três etapas denominadas de pré-obra, obra e pós-obra, envolvendo os atores vinculados ao contexto local - Pró Mover, Caixa Econômica Fede- ral, Entidades locais, Fornecedores de mão de obra e materiais de construção e Associados beneficiários. Geralmente, essas etapas são realizadas no período de tempo de dez meses.

Cabe ressaltar que todas as ações e decisões tomadas em cada etapa devem seguir rigorosamente a legislação vigente sobre o assunto, elaborada pelo Ministério das Cidades e Caixa Econômica Federal, que dispõem de todas as normativas orientadoras para a execução do Programa pela Entidade Organizadora Pró Mover. Dessa forma, a Pró Mover dispõe de um roteiro prévio de como as etapas serão realizadas, buscando adequar esse processo as especificidades de cada município. Ou seja, o poder de decisão dessas entidades, sobre o planejamento do PNHR, é anulado diante das diretivas do poder central.

A primeira etapa, pré-obra, consiste no planejamento das ações e na mobilização dos atores sociais e dos interessados em associar-se à Pró Mover para receber o benefício. A etapa denominada Obra é o período de construção da casa. Na última etapa, Pós-obra, realiza-se a prestação de contas e avaliação final do Programa. Cabe salientar que a execução do PNHR não se restringe apenas ao benefício da casa, mais também à promoção do desenvolvimento e qualidade de vida para as famílias, conforme ressalta um dos técnicos responsável pelo projeto de engenharia do Programa:

Há muitos prefeitos que falam em qualidade de vida e tal, eu vejo que o conceito deles de qualidade de vida é uma coisa bem restrita, ou seja, pavimentar a rua. Esse conceito deve ser um pouco mais abrangente, não apenas considerar as coisas básicas, como pavimentação e esgoto sanitário, mas também uma preparação cultural das pessoas, valorização dos produtos regionaise fazer com que as pessoas participem da tomada de decisão (Entrevista ao arquiteto responsável técnico pelos projetos de engenharia).

No primeiro período de execução do Programa (etapa pré-obra), representantes de entidades de cada município (Prefeituras, Sindicatos e Associações municipais), juntamente com representantes associados da Pró Mover, realizam um planejamento das ações a serem realizadas nas comunidades. Nessa etapa, os envolvidos das diferentes partes, reúnem-se com o objetivo de discutir como o PNHR será implementado 
no município e eleger, por meio de consenso, a equipe gestora do PNHR naquele município.

Com o auxílio do Centro de Referência de Assistência Social (CRAS), é realizado pela equipe técnica social da Pró Mover um diagnóstico, objetivando obter informações a respeito das comunidades e famílias do meio rural e, dessa forma, é elaborado um plano de ação em conjunto com a equipe gestora do PNHR, traçando os objetivos e ações referente ao setor de habitação rural a serem implementadas naquele município.

A equipe gestora do Programa realiza visitas às moradias dos agricultores, efetuando uma entrevista sobre o perfil socioeconômico. Dentre os critérios de seleção definidos em assembleia, por consenso, pelos associados da Pró Mover, estão: a) Familias que não possuem casa própria e que se enquadram no Grupo I de beneficiários (renda bruta anual de R $\$ 15.000,00$ ); b) Familias com mulheres responsáveis pela unidade familiar; c) Familias com pessoas deficientes ou idosas; d) Familias residentes em área de risco ou insalubres ou que tenham sido desabrigadas; e) Familias que tenham o maior número de filhos menores de idade; f) Familias que tenham pessoas estudando, ou em programas de qualificação profissional (ASSOCIAÇÃO PARA O DESENVOLVIMENTO SOCIAL E APERFEIÇOAMENTO DO CIDADÃO, 2013a).

A partir do diagnóstico realizado na etapa Pré-obra e da seleção das famílias, a equipe gestora do Programa propõe às famílias a associação na entidade Pró Mover, com o objetivo de receber o benefício da habitação. Nesse momento, inicia-se a execução das ações, como a coleta e a produção de documentos dos associados, bem como a elaboração dos projetos de engenharia e trabalho técnico social pela Pró Mover. Esses são avaliados e aprovados pela Caixa Econômica Federal e Ministério das Cidades, ou seja, a decisão final fica a cargo desses entes.

O projeto de engenharia consiste na elaboração da planta arquitetônica e no planejamento das obras pela equipe de engenharia. $\mathrm{O}$ projeto de trabalho técnico social, denominado de "Projeto Social: Aqui é o Meu Lugar", é realizado por uma equipe multidisciplinar da Pró Mover juntamente com associações, sindicatos e prefeituras das localidades. Nesse Projeto, em um primeiro momento, é realizada uma pesquisa sobre a área de intervenção e características da população beneficiária, bem como as ações que deverão ser realizadas.
Posteriormente, são realizadas atividades com os interessados, como reuniões, dias de campo, dinâmicas, com a intenção de trabalhar em conjunto, trocar experiências entre os participantes, abrindo-se para a participação do público diretamente envolvido, visando ressaltar a importância de valorizar a moradia e qualidade de vida dos beneficiários. Esse projeto é executado durante a construção das casas. Os beneficiários são convocados a participarem. Observa-se que, nesses encontros, grande parte dos beneficiários participa.

As atividades desenvolvidas neste Projeto Social englobam os seguintes temas:

a) Orientações gerais para a obra: essa atividade visa traçar as metas e ações de execução da construção, com orientações técnicas para o bom andamento da obra, qualidade e resistência da casa, agilidade na construção, conclusão e melhor aproveitamento do material. Além da presença dos associados beneficiários, participam desta atividade os profissionais da construção civil contratados.

b) Qualidade de vida: busca promover mais saúde e bem-estar para as famílias. Nessa atividade são realizadas diversas oficinas sobre consumo adequado dos alimentos, prática de exercícios físicos, hortas caseiras, plantas medicinais, ajardinamento e embelezamento da propriedade, importância da preservação ambiental, uso adequado de agrotóxico na lavoura, saneamento básico, água, destino correto do lixo (orgânico em forma de compostagem e seco através da reutilização e reciclagem).

c) Participação social: objetiva ressaltar a importância da participação da sociedade nas decisões públicas, bem como incentivar o envolvimento por meio de entidades como sindicatos, cooperativas e associações, de forma a fortalecer a classe agricultora. Nessa atividade são tratados temas como gestão dos recursos públicos, orçamento público, importância de pagar impostos, participação cidadã, sindicalismo, cooperativismo e associativismo.

d) Empreendedorismo e geração de renda: essa atividade tem o propósito de incentivar as famílias beneficiárias a buscarem novas alternativas de renda, diversificação na produção da propriedade rural - cultivo de hortaliças, plantas medicinais, frutas, piscicultura, entre 
outros - tendo em vista que na região ainda está muito presente a cultura do fumo.

Essas ações valorizam a história, experiências, cultura e vivências do grupo, construindo novos referenciais de convivência e a incorporação de novos valores e de comportamentos (Projeto de Trabalho Técnico Social - Empreendimento Perimbó - 39UH), imprimindo elementos das categorias de desenvolvimento centrado em valores (WOLFE, 1976 apud ANDION, 2003) e sustentabilidade cultural (SACHS, 2002).

É certo que o estímulo à formação de organizações colaborativas para participação na gestão pública, fortalecendo assim valores de cooperação e solidariedade entre os beneficiados, bem como a informação e o esclarecimento e questóes relacionadas ao âmbito público, o resgate e valorização de elementos da cultura local, evidenciam essa relação. E sendo a igualdade participativa e a autonomia, princípios da participação cidadã, esse Projeto, por meio de discussões e explanações deveria promover a consciência política dos beneficiados, contribuindo assim para esse processo. Entretanto, é possível observar que, mesmo se tratando de temas como participação, o mais importante entre os beneficiários é a necessidade de eles assumirem a responsabilidade pela execução de políticas governamentais e não tanto para o envolvimento em espaços institucionais, de planejamento das políticas e pressão social, como o Sistema Nacional de Habitação e de Interesse Social.

Os projetos sociais, elaborados desde 2012, apresentam no seu diagnóstico situações precárias com relação às áreas de intervenção. Com relação ao destino do lixo, em algumas comunidades há coleta de lixo, em outras, o lixo é queimado ou enterrado. Nas casas não há serviço de abastecimento de água, a água é da nascente ou de poço artesiano. O sistema de esgoto e o saneamento são precários, já que muitas comunidades não possuem essa infraestrutura. Grande parte das famílias beneficiárias reside em domicílios rudimentares de madeira, tendo na sua maioria banheiros inadequados. É também comum a presença de casas em situação de risco, como áreas de alagamentos, deslizamentos, desmoronamento e enchentes. Essa realidade demonstra a falta de condições mínimas de qualidade de vida para esses agricultores.
Considerando esse diagnóstico e conforme enfatizado no Projeto de Trabalho Técnico Social Empreendimento Perimbó - 39UH (ASSOCIAÇÃO PARA O DESENVOLVIMENTO SOCIAL E APERFEIÇOAMENTO DO CIDADÃO 2013b, p. 18):

Ter a casa própria para muitas famílias significa o objetivo maior de sua existência. Portanto, é necessária a realização de um trabalho social, com as características que este apresenta para se ter uma preparação das famílias antes e durante a construção, delimitando papéis, resguardando a dignidade do bem viver e morar.

Nesse sentido, entende-se que a construção das unidades habitacionais e a realização do trabalho social com as famílias é um fator determinante para a inclusão social e para a qualidade de vida dos agricultores, pois, a partir disso, elas passam a dispor de endereço fixo, em locais fora de risco e com condições mínimas de vida, contribuindo assim para as dimensões da sustentabilidade social, sustentabilidade econômica e sustentabilidade ecológica e ambiental.

Ainda na primeira etapa do Programa, é realizada uma assembleia com o grupo de beneficiários de cada município para eleição, por meio de votação, da Comissão de Representantes do Empreendimento (CRE). A CRE é composta por beneficiários das mais diferentes comunidades dentro do município, de forma a ser o mais plural possível, possibilitando também o aumento da inclusão social. Essa comissão, juntamente com a Pró Mover, é responsável pela gestão dos recursos financeiros e prestação de contas de forma transparente. Os membros possuem a função de acompanhar o andamento das obras, atividades de compra, recebimento e distribuição de material de construção, emissão de notas fiscais pelas lojas de materiais e declaração da destinação dos recursos liberados para pagamentos de serviços, bem como dialogar com os demais beneficiados de forma que todas as etapas sejam também pensadas e avaliadas por eles.

A Comissão toma as decisões referentes à destinação dos recursos públicos por meio de consensos entre os integrantes, que dentro desses espaços possuem igualdade participativa e na etapa da pré-obra estão preparados para ter autonomia nesse processo. Nessa etapa identificou-se, desse modo, aspectos das dimensões sustentabilidade política (SACHS, 2002) e participação cidadã com o envolvimento dos be- 
neficiários e integrantes da Pró Mover nas etapas de planejamento dos recursos a serem utilizados (e não das políticas em si), execução, monitoramento e avaliação do Programa, aliando espaços de participação direta a espaços de participação representativa. Ainda assim, como se destacou anteriormente, as decisões tomadas nesse espaço devem seguir os parâmetros preestabelecidos pelo poder público.

Após a elaboração do projeto de intervenção habitacional pela equipe gestora do Programa e aprovação pela Caixa Econômica Federal e Ministério das Cidades, o Ministério da Fazenda repassa para a Caixa os recursos financeiros para a execução do Programa. Inicia-se aqui a segunda etapa, denominada de obra. A CRE e os associados tomam diversas decisões, como escolher a(s) loja(s) de materiais de construção para fornecimento e contratar os profissionais de mão de obra para a execução dos serviços.

De certo modo, nessa fase identificou-se a existência de interesses de alguns beneficiários no sentido de favorecer determinadas lojas de material de construção ou os fornecedores de mão de obra da sua confiança, não submetendo, assim, seus interesses ao bem comum, que seria a contratação de serviços de qualidade, com o menor custo. As propostas são lançadas pelos beneficiários e colocadas em votação, levando em consideração os preços cotados e compatíveis com o orçamento para a construção das casas.

Ressalta-se que, como prioridade definida em Assembleia da Pró Mover, os fornecedores devem prioritariamente estar localizados e residirem no município o qual serão construídas as casas, agilizando assim a prestação do serviço. O motivo desta prioridade é o fato de gerar renda na comunidade, utilizando dos próprios recursos existentes no local, movimentando a economia do município, conforme enfatiza um dos entrevistados: "A questão dos pedreiros, assim [...] teve duas mãos de obra que vieram de fora, o restante é tudo mão de obra local" (Entrevista ao integrante do setor de projetos de trabalhos sociais da equipe técnica da PRÓ MOVER).

Para a construção, utiliza-se o regime de autoconstrução assistida, modalidade escolhida pela Pró Mover que permite a participação dos beneficiários na execução da política e construção da sua residência. O método utilizado pela Pró Mover objetiva garantir a qualidade e a satisfação dos beneficiários com a casa, além do custo na contratação direta de lojas de materiais de construção e fornecedores de mão de obra ser mais barato. Geralmente, na execução desses programas do governo, as Entidades Organizadoras contratam uma construtora (regime de empreitada global), impedindo assim a participação dos beneficiários nessa etapa bem como escolha, por parte das famílias, da cor de tinta e o modelo do piso da casa, por exemplo.

Além disso, cabe ainda a CRE e a cada família beneficiária a fiscalização do andamento das construções e de todo o projeto, conforme planejado no início, ou seja, o controle social. É responsabilidade da CRE o gerenciamento e a liberação dos recursos aplicados para a construção das unidades habitacionais, de acordo com as etapas e o andamento das obras. Posto isso, vale ressaltar que considerando as 724 unidades habitacionais na região, o montante de recursos investido por meio desse Programa soma cerca de $\mathrm{R} \$ 20.634 .000,00$. Para a mão de obra são destinados $\mathrm{R} \$$ 6.516.000,00 e para os fornecedores de materiais de construção $R \$ 14.118 .000,00$. A construção das casas foi realizada por aproximadamente 370 profissionais, contemplando pedreiros, carpinteiros, pintores, encanadores e eletricistas. O fornecimento dos materiais ficou por conta de 30 lojas de materiais de construção da região, oportunizando empregos nos municípios pela elevada demanda.

Isso vem ao encontro das características eficiência na alocação dos recursos e valorização dos próprios recursos do local, contribuindo para as categorias de sustentabilidade econômica (SACHS, 2002), ênfase do local (ANDION, 2003) e desenvolvimento centrado em valores no sentido de se solidarizar com os grupos locais (WOLFE, 1976 apud ANDION, 2003).

O projeto arquitetônico da casa é padrão, de acordo com as especificações mínimas orientadas pelo Ministério das Cidades, devendo rigorosamente seguir o projeto aprovado pela Caixa Econômica Federal. O plano foi elaborado prevendo a mobilidade de pessoas portadoras de necessidades especiais, como cadeirantes em todos os cômodos da casa, bem como a possibilidade de ampliação da unidade habitacional, podendo essa ser realizada pela família beneficiária com seus recursos próprios, posteriormente a finalização das obras. Isso, em termos de participação cidadã e de sustentabilidade política, evidencia 
uma limitação, visto que o projeto não possibilita sua adequação ao tamanho da família $e$ às necessidades de cada beneficiário.

Em se tratando das características de sustentabilidade ambiental (SACHS, 2002), as ações realizadas objetivam promover um desenvolvimento que respeite os limites do meio ambiente. Como destaca um dos beneficiários "O valor do projeto é limitado, então eu penso que isto é um ponto fraco, pois infelizmente produzir uma casa totalmente sustentável é mais oneroso do que construir uma casa de forma comum." (Entrevista ao associado beneficiário do município de Ituporanga).

Algumas ações de prevenção ao meio ambiente são realizadas, conforme ressalta o entrevistado associado do município de Lontras: "Conseguimos até aprimorar o sistema de fossa e filtro, colocamos aquela vala de infiltração que é de baixo custo e resolve a questão de poluição ambiental de dejetos". Além dessas medidas, a Pró Mover orienta e fiscaliza a construção das casas. "O fato de monitorar para que as casas não sejam construídas em área de risco ou condenadas e também áreas de tratamento de efluentes, mostra que a questão ambiental vem sendo respeitada na íntegra". Dessa forma, a execução desse Projeto busca mapear e planejar as construções, contendo a poluição, queimadas, esgotos inadequados e construções irregulares que causam sérios impactos para o meio ambiente.

Nessa etapa, é essencial a participação dos associados beneficiários na construção das moradias. Entretanto, existem famílias que não participam e não atuam da forma como deveriam, deixando grande parte da responsabilidade por conta da CRE a da Associação. Alguns dos envolvidos relatam que apenas querem receber a casa e dizem confiar na Pró Mover. Quando convocados para as reuniões mensais de avaliação do grupo, os beneficiários opinam sobre o andamento da obra e os seus problemas. Porém, ao se tomar decisões sobre ações a serem desenvolvidas para resolução de problemas, os associados pouco participam. Isso porque nem sempre seus indicativos, como a possibilidade de adequação das ações do Programa aos seus anseios, são levados a cabo pelo Programa.

A última etapa, denominada de Pós-obra, ocorre depois da finalização da construção das casas e realização das atividades do Trabalho Social. Nessa etapa realiza-se a festa de inauguração que ocorre na casa nova de uma das famílias, com a presença de repre- sentantes de todas as entidades que compõem a rede de cooperação local. O encontro proporciona uma apresentação da prestação de contas pela CRE, bem como avaliação final da execução do Programa, sendo esta apresentada ao Ministério das Cidades e Caixa Econômica Federal. Nesse processo também há o incentivo para a comunidade local planejar a continuidade dos trabalhos, utilizando de suas vantagens locais e suprindo as necessidades da população, proporcionando assim o desenvolvimento da sua comunidade.

Tendo em vista os objetivos desses Programas, considera-se que a atuação dos atores envolvidos nesse processo de parceria, de aliança e de cooperação teve uma contribuição importante para o desenvolvimento local da Região do Alto Vale do Itajaí, ainda que com algumas fragilidades.

Quando se trata de sustentabilidade, vale ressaltar que o objetivo prático do PNHR, de acordo com um dos representantes da Caixa Econômica Federal, "fixar o agricultor no campo, produzindo alimentos", ou seja, incentiva a permanência do agricultor no campo, preservando a cultura das famílias nas pequenas propriedades e dos "[...] agricultores que sempre estiveram à margem".

Por conseguinte, a construção de uma nova casa, a melhora da qualidade de vida e o aumento da autoestima dos agricultores garantem maior inclusão social, que diz respeito à qualidade de vida decente $e$ à diminuição da exclusão social, conforme enfatiza Sachs (2002), quando conceitua sustentabilidade social. As características relativas à sustentabilidade cultural, elencadas nos dados já apresentados, também podem ser observadas quando se referem à valorização da cultura e valores dos agricultores locais, incentivando a família a morar e utilizar recursos, formas de produzir e conhecimento daquela comunidade em questão. A responsável técnica pelos projetos de trabalhos sociais ressalta a evolução e a importância desse Programa para a região:

O meio rural está mudando, o fato de as pessoas terem a sua casa nova, bonita, com qualidade de vida, com conforto, vai estimular também a ficar mais no campo. Por que agora, a gente anda pelo interior e vê um cenário diferente. O pessoal comenta: "Nossa, só se vê as casinhas." Sim! São casinhas, mas são casinhas novas, bonitas e de qualidade. 
Com relação à sustentabilidade econômica, observou-se que o regime de construção das casas, adotado pela Pró Mover "autoconstrução assistida", proporcionou a geração de emprego e renda para o setor de construção civil da região, oportunizando os fornecedores de materiais de construção e mão de obra, além de incentivar a participação dos agricultores como gestores das obras. Sobre a questão da sustentabilidade ambiental, foi possível perceber que o meio ambiente vem sendo respeitado, impedindo a construção em áreas de risco e controlando a ocupação do meio rural por meio da fixação do agricultor no campo.

Ainda que a participação seja uma prorrogativa do Programa e da rede pública de cooperação, já que ela ainda é bastante limitada, como ressalta a responsável técnica pelos projetos de trabalhos sociais "Realmente não funciona como a gente gostaria. A grande dificuldade é porque já existe uma cultura das pessoas no local que durante muitos anos, houve muito assistencialismo. As pessoas sempre receberam tudo pronto, de mãos dadas". Uma associada beneficiária do município de Rio do Oeste afirma "As pessoas estão muito individualistas, só pensam nos seus interesses, $e$ muitas delas nem compreendem que as casas são feitas em grupo, que um deve colaborar e ajudar o outro".

Esse aspecto é um grande limitante para a efetividade da rede pública de cooperação, de desenvolvimento local e dos objetivos do Programa, já que a participação cidadã, caracterizada pelo envolvimento das comunidades nas decisões políticas, de forma qualificada, deveria pressuposto central deste processo. Ou seja, participar não é apenas executar as ações do Programa, mas sim decidir sobre seus rumos, e isso não ocorreu no desenvolvimento do PNHR pela rede que a Pró Mover atua. Acredita-se que parte da resistência dos beneficiados de participar das decisões nesse processo se deve à limitação do poder de decisão dos espaços existentes dentro do Programa, principalmente no que se refere à escolha do projeto arquitetônico, da adequação ao número de integrantes e de necessidades familiares, entre outras. Também se atribui esse cenário ao fato de muitas vezes não terem suas demandas e solicitações atendidas e, como destacado anteriormente, por se tratar do tema participação no Projeto Social se faz referência eminentemente à execução das políticas, limitando assim o potencial participativo.
Entretanto não se pode anular o potencial transformador dessa experiência em função dessa evidência. A mudança comportamental é algo que ocorre a longo prazo, e pode ser que futuramente seja possível colher os frutos plantados nesse processo, visto que os atores advindos das comunidades, ao participarem de espaços de discussão e se articularem em organizações civis (como o estimulado no Projeto Social), podem adquirir maior consciência política de forma a pressionar o poder público por maior poder de decisão, consolidando assim processos de participação cidadã.

Nesse sentido, como forma de aumentar o potencial transformador da participação, seria necessário conhecer as características culturais da comunidade local, seu envolvimento histórico nas decisões políticas, para melhor delinear estratégias que busquem e envolvimento dos associados beneficiários com o intuito de pressionar o poder público em espaços como SNHI, para possibilitar a participação deles em todo o processo, desde o planejamento até a execução de ações do PNHR.

\section{Considerações Finais}

O estudo apresentado aqui teve o intuito de contribuir para o campo da gestão social, de forma a identificar o real potencial transformador e de impulso ao desenvolvimento local, de redes públicas de cooperação, que constituem uma nova forma organizacional com o horizonte de radicalização democrática e ampliação da cidadania. Isso porque, para que se constituam efetivamente, os processos democráticos devem promover o compartilhamento do poder sobre as decisões políticas, evidenciando a inclusão de atores historicamente à margem da gestão pública.

A experiência relatada aqui evidenciou que os moldes nos quais se delinearam as políticas habitacionais, nomeadamente o Programa Nacional de Habitação Rural, apresentam potencialidades no que tange ao desenvolvimento local, mas que ainda precisam de aprimoramento, levando em consideração aspectos e peculiaridades locais e dando voz aos cidadãos. Como ponto de partida teve-se a ideia de que as redes públicas de cooperação estimulam o processo de desenvolvimento e, através da experiência da Pró Mover com a rede de cooperação do PNHR no Alto 
Vale do Itajaí, pode-se identificar quais as principais contribuições desse tipo organização para este fim.

Diante das análises e dos resultados apresentados, constatou-se que a Pró Mover, com a rede pública de cooperação local do PNHR, que envolve o Ministério da Fazenda, Ministério das Cidades, Caixa Econômica Federal, Entidades locais, Fornecedores de matérias-primas e mão de obra e beneficiários, contribuiu para o desenvolvimento da região do Alto Vale do Itajaí, principalmente em aspectos como incremento social em termos de qualidade de vida, valorização da cultura e modos de vivência do agricultor, além da geração de emprego e renda para o setor de construção civil e respeito ao meio ambiente, através do planejamento das construções.

Por outro lado, naquele que deveria ser o objetivo central da rede pública de cooperação - ampliação da cidadania e radicalização democrática - encontrou-se a maior limitação desse Programa e efetividade da rede. A própria rede do PNHR evidenciou uma assimetria de poder e participação, já que as decisões políticas essenciais ficam a cargo do Ministério da Fazenda e Ministério das Cidades, restando aos demais atores a execução das políticas de acordo com a legislação já instituída por esses órgãos.

Portanto, percebe-se que os entes locais, mais próximos da realidade dos cidadãos, participaram apenas em alguns níveis de decisão - execução, monitoramento e avaliação - prejudicando assim a descentralização política. E isso se imprimiu ao longo da realização do Programa, pois ainda que existam canais de participação dos beneficiários nesse processo, o planejamento e a elaboração dos projetos técnicos e sociais devem ter a aprovação do Ministério das Cidades.

O envolvimento dos cidadãos no planejamento das políticas do Programa possibilitaria uma adequação maior às demandas sociais, problemáticas locais, contribuindo para todos os elementos do desenvolvimento sustentável.

Por fim, como reflexão acerca das redes e moldes das políticas habitacionais, verificou-se a necessidade de reformular e de repensar a participação e as atribuições dos atores envolvidos, de forma que as redes organizadas nesse campo possibilitem uma efetiva descentralização da gestão pública, com relações mais horizontais, como deveria ocorrer nesse tipo de articulação.

\section{REFERÊNCIAS}

ANGROSINO, M.V.; PEREZ, K. A. Rethinking observation. In: DENZIN, N. K.; LINCOLN, Y. S. (Ed.). Handbook of qualitative research. Thousand Oaks: SAGE, 2000.

ANDION, C. Análise de redes e desenvolvimento local sustentável. Revista de Administração Pública, [S.l.], v. 37, n. 5, set.-out. 2003.

ASSOCIAÇÃO PARA O DESENVOLVIMENTO SOCIAL E APERFEIÇOAMENTO DO CIDADÃO. Ata da

Assembleia Geral, de 16 de junho de 2013a.

ASSOCIAÇÃO PARA O DESENVOLVIMENTO SOCIAL E APERFEIÇOAMENTO DO CIDADÃO. Ata de eleição da Comissão de Representantes do Empreendimento Hortência, de 12 de novembro de 2013b.

ASSOCIAÇÃO PARA O DESENVOLVIMENTO SOCIAL E APERFEIÇOAMENTO DO CIDADÃO. Projeto de

Trabalho Técnico Social - Empreendimento Perimbó - 39UH. 2013c.

BARDIN, L. Análise de conteúdo. Portugal: Edições 70, 1977.

BRASIL. Contratações efetuadas através do PNHR - 2009 a julho de 2013. Brasília, DF: Ministério das Cidades, 2013a.

BRASIL. Constituição (1988). Constituição da

República Federativa do Brasil. Brasília, DF: Senado, 1988.

BRASIL. Estatuto da Cidade. Lei n. 10.257, de 10 de julho de 2001. [2001]. Disponível em: <http://www. planalto.gov.br/ccivil_03/leis/leis_2001/110257.htm > . Acesso em: 16 nov. 2013.

BRASIL. Política nacional de habitação. Brasília, DF: Ministério das Cidades, novembro, 2004.

BRASIL. Lei n. 11.977, de 7 de julho de 2009. [2009]. Disponível em: <http://www.planalto.gov.br/ccivil_03/ ato2007-2010/2009/lei/l11977.htm > . Acesso em: 16 nov. 2013.

BRASIL. Portal do Ministério das Cidades. [2013b]. Disponível em: <http:/www.cidades.gov.br/index.php/ home.html>. Acesso em: 16 nov. 2013. 
CANÇADO, A. C. Fundamentos teóricos da gestão social. 2011. 246 f. Tese (Doutorado em Administração) - Universidade Federal de Lavras, Lavras, 2011.

COMISSÃO MUNDIAL PARA O MEIO AMBIENTE E DESENVOLVIMENTO (CMMD). Our common future: the Brundtland report. Oxford: Oxford University Press, 1987.

CRUZ, J. A. W.; MARTINS, T. S.; QUANDT, C. O. Redes de cooperação: Um enfoque de governança. Revista

Alcance - Eletrônica, [S.l.], v. 15, n. 2, UNIVALI, maioago. 2008.

FEDOZZI, L. et al. Participação, cultura política e cidades. Sociologias, [on-line], [S.l.], v. 14, n. 30, p. 14-44, 2012.

FISCHER, T.; MELO, V. P. Organizações e interorganizações na gestão do desenvolvimento sócioterritorial. Revista Organizações \& Sociedade, [S.l.], v. 11, ed. especial, p. 13-41, 2004.

\section{FURTADO, C. Pequena introdução ao}

desenvolvimento: enfoque interdisciplinar. São Paulo: Editora Nacional, 1980. p. 1-27.

LEMOS, M. V. S. Cadeias produtivas solidárias como modelo de desenvolvimento Regional sustentável: o caso do Baixo Sul da Bahia. 2011. 68 f. Trabalho de conclusão de curso (Graduação em Economia) Faculdade de Ciências Econômicas da UFBA, Bahia, 2011.

MARCONI, M. A. Técnicas de pesquisa: planejamento e execução de pesquisas, amostragens e técnicas de pesquisa, elaboração, análise e interpretação de dados. 7 . ed. 3. Reimpr. São Paulo: Atlas, 2010.

MARTINS, S. R. O. Desenvolvimento Local: questões conceituais e metodológicas. Revista Internacional de Desenvolvimento Local, [S.I.], v. 3, n 5, p. 51-59, setembro, 2002.

MOREIRA, V.; VIDAL, F. A. B.; FARIAS, I. Q.

Empreendedorismo Social e Economia Solidária: um estudo de caso da rede de desenvolvimento local integrado e sustentável da comunidade do Grande Bom Jardim. 2008. Disponível em: <http://cac-php.unioeste. $\mathrm{br} /$ projetos/casulo/docs/emp_soc_ec_sol.pdf > . Acesso em: 10 set. 2013.
MOURA, S. A construção de redes públicas na gestão local: algumas tendências recentes. Revista de

Administração Contemporânea, Curitiba, v. 2 n. 1 jan.abr. 1998.

MULS, L. M. Desenvolvimento local, espaço e território: o conceito de capital social e a importância da formação de redes entre organismos e instituições locais. Revista Economia, Brasília, DF, v. 9, n. 1, p. 1-21, jan.-abr. 2008.

NOGUEIRA, M. A. Um Estado para a sociedade civil: temas éticos e políticos da gestão democrática. 2. ed. São Paulo: Cortez, 2004.

SACHS, I. Caminhos para o desenvolvimento sustentável. Rio de Janeiro, Garamond, 2002.

\section{SCHERER-WARREN, I. Cidadania sem fronteiras:} ações coletivas na era da globalização. São Paulo: Hucitec, 1999.

SEN, A. Desenvolvimento como liberdade. São Paulo: Companhia das Letras, 2000.

SILVA, S. R. M. Indicadores de sustentabilidade urbana: as perspectivas e as limitações da operacionalização de um referencial sustentável. 2000. 260 f. Dissertação (Mestrado em Engenharia Urbana) Universidade Federal de São Carlos, São Carlos, 2000.

SUBIRATS, J. Como ficou o espaço local nesta grande transformação econômica e social que estamos vivendo? In: TENÓRIO, F. G. Cidadania e desenvolvimento local: critérios de análise. Rio de Janeiro: Editora FGV, 2012. p. 7-12.

TAVARES, M. C.; FIORI, J. L. Poder e dinheiro: uma economia política da globalização. Petrópolis: Vozes, 1997.

TENÓRIO, F. G. Cidadania e desenvolvimento local: critérios de análise. Rio de Janeiro: Editora FGV, 2012.

. (Re) visitando o conceito de gestão social.

Ensaios desenvolvimento em questão, [S.I.], n. 5, ano 3. Unijuí, jan-jun. 2005.

ZAPATA, T.; AMORIM, M.; ARNS, P. C.

Desenvolvimento territorial à distância. Florianópolis: SEaD/UFSC. 2007. 